\title{
Implementation Agreement By Mixed Marriage Based On Act No. 1 of 1974 Concerning Marriage After Constitutional Court Ruling No. 69 / PUU-XIII / 2015 (Study of Notary Role)
}

\begin{abstract}
Riyanto $^{1}$, Wachid Aryanto ${ }^{2}$ and Arief Cholil ${ }^{3}$
Abstract. The bride and groom's candidate before the marriage takes place, can make a "Marriage Agreement" to provide legal certainty related to property and for legal protection against third parties. Primarily for mixed marriages, the bride and groom are subject to two different legal systems according to their nationality. , the agreement made by the Marriage Agreement has been amended by the Decision of the Constitutional Court Number: 69 / PUU-XIII / 2015 dated October 27,2016 . The positive implication for the intermarriage is that it can have land rights in the form of Ownership Rights (HM) and Right to Build (HGB) without having to divorce first. Then, this research intends to discuss the practice of the Implementation of Mixed Marriage Agreements based on Act No. 1 of 1974 concerning Marriage after the decision of the Constitutional Court Number: 69 / PUU-XIII / 2015. The purpose of this study was to describe the role of the notary in the deed Mating Agreement and its implementation after the decision of the Court in question, and to know the legal implications of the couples in mixed marriages. The method in this research is juridical empirical research methods.

Keywords: Mating Agreement; Marriage Commingling; Deed; Decision of the Constitutional Court; Marriage Act.
\end{abstract}

\section{Introduction}

Zoonpoliticon as human beings in real life in the world plays a role not only as individual beings, but also as social beings who generally can not live alone only, therefore most people will be looking for a life partner to raise a family. In order has legal certainty in the relationship, then the man was carrying out marriages conducted under the provisions of the law on one or both sides bride based on nationality. However, in its development of property issues is one of the principal factors or the base of which can cause many disagreements or tension in a marriage. Not infrequently related problems arise when a property of the marital relationship ended. Moreover for couples in mixed marriages, the bride and groom bow on two different legal systems in accordance with their citizenship status. So with the marriage agreement it will have a significance that is going to allow one couple an Indonesian citizen (citizen) to the right to own property assets under Own Right (HM) or Built Usage Right (HGB). The rights in some settings Act be forfeited if married to foreigners (WNA) in the absence of the Marriage Covenant.

\footnotetext{
${ }^{1}$ Student of Master of Notary Law Faculty of Law, Universitas Islam Sultan Agung email: riyanto69sh@gmail.com

2 Students of Master of Law, Faculty of Law, Universitas Islam Sultan Agung email wachidaryanto46@gmail.com

${ }^{3}$ Lecturer in the Faculty of Islam UNISSULA Semarang
} 
The principal purpose is to regulate the holding of wedding agreement between husband and wife what will happen regarding the wealth they bring and or they would earn each. ${ }^{4}$

Moreover, the purpose of mating agreement is made:

- If the assets of one of the parties (husband or wife) is larger than the assets of the other party.

- Both parties (husband and wife) brought in a sizeable property into marital property.

- Each has its own business. When one falls insolvent (bankrupt), the other did not participate bankrupt.

- Against debts made before the marriage, each of which will bear the debt itself. ${ }^{5}$

Relevant provisions in the Civil Code of common property mentioned above is different from the provisions on property that is regulated in Act No. 1 of 1974 concerning marriage, in which section 35 set:

(1) The properties acquired during the marriage become community property;

(2) A treasure inherited from each husband and wife and possessions obtained each as a gift or inheritance, is under the control of each one, all parties do not agree otherwise.

However, in its development when the relevant provisions of the Agreement made Mating amended by the Constitutional Court Decision No .: 69 / PUU-XIII / 2015 dated October 27, 2016 (Constitutional Court Decision No. 69/2015), which is the way out for married couples who do not have a marriage agreement (premarital agreement). In the initial implementation, the Constitutional court's decision raises many questions in the field, especially regarding the rules for the implementation of the decision. Especially for notaries and employees of the marriage registrar, namely the Office of Civil and Religious Affairs Office (KUA). ${ }^{6}$

With the reversal of norms while making the agreement to marry, namely during the marriage bond, then the citizens who are married to foreigners could make arrangements to marry at any time: either before, while, and during the marriage bond, so that the right of the citizen to own land with the status of any rights not blocked again because of the occurrence of unity property by foreigners married couples. If the citizen has already been married to foreigners, but had not made a pact to marry, then the marriage covenant can be made in a period of matrimony. ${ }^{7}$

\footnotetext{
44 Mochammad Djais 2003 Hukum Harta Kekayaan Dalam Perkawinan Semarang: Fakultas Hukum Universitas Diponegoro p. 9

${ }^{5}$ Ibid.

${ }^{6}$ Fairus Harris "Ini Ketentuan Pelaksana Perjanjian Perkawinan Setelah Menikah (Postnuptial Agreement)",https://kantorpengacara.co/ini-ketentuan-pelaksana-perjanjian-perkawinansetelah-menikah-postnuptial-agreement/accessed on October 182018.

7 Zul Fadli S.H. M.Kn. "Perjanjian Kawin Pasca Putusan Mahkamah Konstitusi" https://www.boyyendratamin.com/2017/03/perjanjian-kawin-pasca-putusan-mahkamahkonstitusi.html accessed on October 182018.
} 
The positive implications of this decision for the perpetrators of interbreeding is able to buy the rights to land in the form of HM and HGB without having divorced first partner. Because, during "tricked" when the citizen interbreeding suggested going to buy a house first divorce, then made a covenant marriage (separation of property), then remarried or nominee agreement, meaning that the land purchase on behalf of others. ${ }^{8}$

Constitutional provisions related to the above, some researchers zeroed in on the practice of the time difference of making the marriage contract, especially in couples who both side are Indonesian citizens. Yet few studies concerning the role of the notary in the case of making an authentic deed Mating Agreement for mixed marriages after the decision of the Court in question. Yet given today's complex, cross-border difference is no longer an obstacle that means for the marriage between a citizen with foreigners (WNA). Therefore, this study intends to discuss the practice of the Implementation Agreement Based on the Mixed Marriages Act No. 1 of 1974 on Marriage Following the Ruling of the Constitutional Court Number: 69 / PUU-XIII / 2015 (Study Role of the Notary).

\section{Research methods}

In conducting the research required a method must be appropriate to the type of research done and needs to be systematic and consistent. The method I use in this study is juridical empirical research methods.

Juridical empirical approach is the approach to a problem concerning the matters juridical and realities regarding the Marriage Covenant deed. Empirical legal research or sociological research that is legal research using primary data. ${ }^{9}$

In addition, research conducted based on a scientific method that is part of an empirical approach. This study was also based on the theories of the existing law, the provisions of the legislation in force, nor the opinions of scholars and experts. ${ }^{10}$ As well as based on the example of the Marriage Covenant notarial deed on intermarriage.

\section{Results and Discussion}

In general, the law allows both prospective spouses to make a treaty called "Treaty marriage" or "marriage contract", which is generally in the agreement only concerned about arrangements for the treasure of marriage, which is intended to anticipate problems might arise if the marriage ends. The marriage contract as an agreement regarding the marital property is possible to be made and are held throughout the deviation from the principle or the pattern set by the legislation. ${ }^{11}$

\footnotetext{
8 Agus Sahbani "MK 'Perlonggar' Makna Perjanjian Perkawinan" https://www.hukumonline.com/berita/baca/lt5811d246a9498/mk-perlonggar-maknaperjanjian-perkawinan accessed on October 182018.

${ }^{9}$ Ronny Hanitijo Soemitro Metodologi Penelitian Hukum dan Jurimetri Ghalia Indonesia Jakarta $\mathrm{p} 10$.

${ }^{10}$ Ronny Kountur 2004 Metode Penelitian untuk Penulisan Skripsi dan Tesis PPM Jakarta p 6.

11 R. Soebekti 2004 Hukum Keluarga dan Hukum Waris Jakarta: Internasa p. 8-9.
} 
The marriage contract is a form of engagement, which therefore remains to be made based on the general requirements that apply to be a legal contract. While the terms of an agreement to be able to meet the elements of a legal contract has been stipulated in Article 1320 of the Civil Code. In addition, the Civil Code and the Marriage Act has also been set up in detail about the marriage contract, which basically stated that the mating agreement is common due to their mutual agreement between husband and wife bride.

The marriage contract by origin is a translation of the word "huwelijksevoorwaarden" that exists in the Burgerlijk Wetboek (BW) (Civil Code). This term is contained in the Civil Code, Act No. 1 of 1974 and the Islamic Law Compilation (KHI). Huwlijk itself by language means: marriage between a man and a woman, while voorwaard meaningful terms. Thus, the mating agreement is an agreement (agreement) made by the prospective husband and wife before or during the marriage took place to regulate the consequences of marriage against their property. ${ }^{12}$

In the Civil Code, given some restrictions on the content of the marriage contract, namely:

- Agreement must not be contrary to morality or public order (Article 139);

- Agreement should not deviate from power by the Civil Code is given to the husband as head of household, for example, should not be promised that the wife will have their own residence (Article 140 paragraph (1));

- In the marital agreement should not renounce their right to inherit property left by their children (Article 141);

- In the agreement it should not be determined that in the case of mixed property, owned jointly when it is stopped, the husband or the wife will pay part of the debt that exceeds the balance and mutual benefit (Pasal142);

- In the agreement it should not be generally designated granted to the regulations that apply to a foreign country (Article 143). ${ }^{13}$

In connection with the implementation of the agreement after the mating based Marriage Law Constitutional Court decision No. 69 / PUU XIII / 2015, the authors took a sample of Marriage Mixed Marriage Agreement between Ale (a pseudonym) Italian nationality as the First Party and Lia (pseudonym) Indonesian nationality as the Second Party.

The mating agreement made in January 2018, in the presence of a notary ZULAICHA, Bachelor of Laws, Master of Notary, the Notary in Semarang. But from the beginning of clause listed in the notarial deed which states as follows: "Whereas among the parties have found an agreement to enter into marriage for that the parties have

\footnotetext{
12 R. Soetojo Prawirahamidjojo 1988 Pluralisme dalam Perundang-undangan Perkawinan di Indonesia Airlangga University Press p.57.

${ }_{13}$ Martiman Prodjohamidjojo 2002 HukumPerkawinanIndonesia Jakarta:IndonesiaLegal Center Publishing p.29
} 
agreed and consensus to make arrangements to marry ... "it can be concluded that the mating agreement made before the course marriage contract between them.

In the mating agreement between the two sides set things in outline as follows: Treasure; Rights \& Obligations of both parties; Etc.

\subsection{Treasure}

Related assets, confirmed that between husband and wife there would be no alliance possessions with any name or designation, good fellowship property according to the law or alliance or partnership profits and losses and income results. All property of any nature also remain the property of the parties to bring and or acquired.

But in the mating agreement no further elaborated what is referred to as property. Only differentiated into moving goods and goods not bergerak.Dimana for goods moving by the parties obtained from and by any cause after the wedding was held, shall be proved by evidence of ownership, without prejudice to the rights of both parties to prove their these items or price. As for immovable goods, which can not be proved by evidence of ownership or other documents regarded as belonging to the parties, each for a (half) equal parts.

Further, it is mentioned that the clothes and jewels that exist on the parties, upon termination of the marriage or at the time of the calculation according to the law, is regarded as belonging to the parties who use or are considered as belonging to the parties who use or considered to be owned by those who usually use these items, so that on these items will not be held calculations.

\subsection{Right \& Obligations of Both Parties}

Regarding the rights and obligations of the Parties, in the deed of agreement was agreed that both richness and liabilities of the parties that occurred before or after the marriage took place, remain the rights or obligations of each. Both parties can take care of and defend their rights, both in the acts of management and actions to menurus ownership, control of their own possessions, either move, or not move, and the free enjoyment of his income. For things mentioned, the Second Party has been authorized and approved by the First Party.

Both parties have the right to manage the family finances with the consent of the First Party. And the two sides agreed to carry out the rights and obligations of each as well as possible, including the rights and obligations as husband and wife. Costs for domestic purposes, to educate and nurture children born from their marriage endured by the First Party. Expenditures for the purposes mentioned above are committed by the Second Party, considered to have been carried out with the consent of the First Party.

Debts and bills from the other party arising from these costs above, shall be borne and paid by the First Party and the Second Party can not be charged or sued about it.

\subsection{Etc.}


Besides related property, the agreement also regulates mating other things, in which both sides agree:

- That in principle this marriage is only subject to a monogamous marriage and oppose the polygamy or polyandry;

- Agreed not committing a criminal act against domestic violence (domestic violence), as stipulated in act no. 23 of 2004 on the elimination of domestic violence (domestic violence);

- All forms of violence against household should be excluded both the core and the family members of persons who worked in the house which is a joint residence and / or place of residence of the parties;

- To provide a good and balanced attention to the growth and psychological development of the child;

- To provide a good and balanced attention to the growth and psychological development of the child;

- To provide equal time to the care and education of children;

- To apply the general principles as set out in the convention on child rights and act no. 23 of 2002 on child protection jo. Act no. 35 of 2014;

- That children born from their marriage, obliged to convert to islam, with the ownership of two citizenship and children are free to choose a citizen after the age of 17 (seventeen) years.

Of exposure to the above, it can be concluded that the content of the agreement does not violate the provisions of laws and regulations, so it does not violate the provisions of Article 139-143 of the Civil Code.

It also met the element in the Marriage Law Article 29, namely at the time or before the marriage took place, the two parties by mutual consent can hold a written agreement approved by employees of the marriage registrar, after which it shall also apply to third parties throughout the third party jam. Therefore, the agreement is effective since the marriage took place.

Therefore with the Constitutional Court Decision 69/2015, the provisions of Article 29 of the Marriage Act changed as follows: ${ }^{14}$

- At the time, before it was held, or during the marriage bond, the two parties by mutual consent can file a written agreement approved by the marriage registrar or a notary public servants, after which it shall also apply to third parties throughout the third party jam.

- The agreement can not be passed when breaking the boundaries of the law, religion and morality.

14 Hukum Online "Bisakah Membuat Perjanjian Kawin Setelah Perkawinan Berlangsung (Postnuptial

,https://www.hukumonline.com/klinik/detail/lt583e9ba62c691/bisakah-membuat-

$\%$ 20perjanjian-kawin-setelah-perkawinan-berlangsung-(postnuptial-agreement)? accessed on October 182018. 
- The agreement entered into force since the marriage took place, unless otherwise stipulated in the marriage contract.

- During the marriage takes place, the marriage contract can be the treasure of marriage or other agreement can not be modified or revoked, unless both parties consent to alter or repeal and amendment or repeal it does not harm third parties.

By looking from point number (4) above, it can be concluded that the current treaty already marriage can be changed with a few conditions. In this case the notary plays an important role in providing guidance to both sides, not just a ban on anything that should not be violated in making the content of the marriage contract. But it also matters which may require to be included in the mating notarial deed agreement. Because of this notarial deed would be incomplete if the evidence that disputes will occur in the future.

\section{Closing}

\subsection{Conclution}

Based on the translation of the above can be concluded as follows:

- Although not expressly regulated in various laws, but for the sake of legal certainty especially in terms of proving the validity of the Marriage Covenant. The parties will enter into marriage and want to make a marriage agreement should be made before a notary public. So it is more authentic and have full legal force.

- After court decision No. 69 / PUU-XIII / 2015 in principle agreement has Mating can be made anytime. However, because of this decision still includes new, many married couples who are not yet aware of its entry into force, thus making the marriage covenant are still likely to be made before the wedding and not stated the clause to the "Addendum". Though this clause is important in order to change the contents of the deed of agreement to marry during the marriage if it is necessary in the future.

- Although essentially with their agreement this marriage parties then will have implications permission bride is a citizen to own assets in the form of land with HGB and HM. But in practice found by the author in notarial between Ali and Lia, not listed prominently associated distribution of wealth primarily to asset items do not move.

\subsection{Suggestion}

- Given the importance of the agreement to marry, especially for couples of mixed marriages which in principle is subject to two different legal systems, based citizenship and its relation to the protection of third parties. Notary role in providing guidance to the relevant partner important things what should be regulated under a mating agreement. 
- Notary Deed has the strength of evidence is perfect. However, it would be better if the deed of marriage agreement remain registered to the marriage registrar officials at the Religious Affairs Office (KUA) or the Civil Registry Office.

- So that both sides should take stock whatever property the respective rights and collective rights. Considering one of the spouses is a citizen of Italy, while in the country do not recognize their marriage system "divorce". So in a notarial deed can publicly asserted that the agreement is subject to the legal system of Indonesia. So there is no confusion again in the future.

\section{Bibliography}

[1] Agus Sahbani "MK 'Perlonggar' Makna Perjanjian Perkawinan" https://www.hukumonline.com/berita/baca/lt5811d246a9498/mk-perlonggarmakna- perjanjian-perkawinan accessed on October 182018.

[2] Fairus Harris "Ini Ketentuan Pelaksana Perjanjian Perkawinan Setelah Menikah (Postnuptial Agreement)",https://kantorpengacara.co/ini-ketentuan-pelaksanaperjanjian-perkawinan-setelah-menikah-postnuptial-agreement/_accessed on October 182018.

[3] Hukum Online "Bisakah Membuat Perjanjian Kawin Setelah Perkawinan Berlangsung (Postnuptial Agreement)?" https://www.hukumonline.com/klinik/detail/It583e9ba62c691/bisakah-membuat\%20perjanjian-kawin-setelah-perkawinan-berlangsung-(postnuptial-agreement)? accessed on October 182018.

[4] Martiman Prodjohamidjojo 2002 Hukum Perkawinan Indonesia Jakarta: Indonesia Legal Center Publishing.

[5] Mochammad Djais 2003 Hukum Harta Kekayaan Dalam Perkawinan Semarang: Fakultas Hukum Universitas Diponegoro.

[6] R. Soebekti 2004 Hukum Keluarga dan Hukum Waris Jakarta: Internasa.

[7] R. Soetojo Prawirahamidjojo 1988 Pluralisme dalam Perundang-undangan Perkawinan di Indonesia Airlangga University Press.

[8] Ronny Hanitijo Soemitro Metodologi Penelitian Hukum dan Jurimetri Ghalia Indonesia Jakarta.

[9] Ronny Kountur 2004 Metode Penelitian untuk Penulisan Skripsi dan Tesis PPM Jakarta.

[10] Zul Fadli S.H. M.Kn. "Perjanjian Kawin Pasca Putusan Mahkamah Konstitusi" https://www.boyyendratamin.com/2017/03/perjanjian-kawin-pasca-putusanmahkamah-konstitusi.html accessed on October 182018. 